\title{
COAL VS. PETROLEUM AS ENERGY SOURCE FOR INDIA
}

\author{
Amalesh Sirkar $^{1}$, Biswajit Mandal ${ }^{2}$ \\ ${ }^{I}$ Formerly, Dean of School of Chemical Engineering, Food \& Biotechnology Haldia Institute of Technology \\ ${ }^{2}$ Haldia Institute of Technology, Haldia, West Bengal Department of Chemical Engineering, \\ Haldia Institute of Technology, Haldia, West Bengal
}

\begin{abstract}
Coal as such has been used in Power Plant as a fuel for long and can be converted to liquid fuel in a coal liquefaction plant to supply Naphtha for Petrochemical Industries and Diesel and Petrol for running vehicles. The cost of producing liquid from coal ranges from $\$ 35$ to $\$ 60 /$ bbl whereas crude Petroleum derived similar products' cost vary anywhere from $\$ 50$ to $\$ 100 /$ bbl mainly due to crude price variation in International Market since the processing cost of crude in a Refinery is nominal i.e. It varies from \$1 to \$1.5 / bbl under Indian scenario. However, under Indian scenario coal ash handling and disposal is a major problem due to high ash coal in a coal Refinery whereas in a petroleum Refinery there is no such problem. Since in India Petroleum Reserve is very little in comparism to demand of Petroleum Products and in order to meet the demand crude petroleum is imported from Middle Eastern countries there is huge drainage of India's Foreign Exchange. Thus, coal may be an alternative under Indian scenario since coal reserve in India is about 300 billion tons out of which 50\% is Bituminous coal that can be easily liquefied to various products as mentioned above. In this article comprehensive discussions on different aspects of a coal refinery and that of a Petroleum Refinery have been presented.
\end{abstract}

Key Words: Coal, Petroleum, Indian Reserve;

\section{INTRODUCTION}

Coal and Petroleum have been and are still being used as energy source for generation of power and for running vehicles respectively. Also, naphtha is available from crude petroleum as feed stock for Petrochemical Industries. In India oil \& gas reserves in only $0.8 \%$ of world reserve and indigenous production hardly meets $25 \%$ of our present oil demand. India imported $75 \%$ of its oil requirement in 200405 which is expected to rise to $94 \%$ by the year 2030 costing $\$ 2000$ billion a year which is too high for India to afford. On the other hand India's coal reserve is 300 billion tons which is $10 \%$ of world reserve, and $50 \%$ of it is Bituminous coal that is easily liquefiable to products equivalent to naphtha, petrol, kerosene, diesel and fuel oil derived from crude petroleum. At the present rate of use of coal India's reserve is going to last for more than 75 to 100 years (1). In this paper 3 different leading coal liquefaction processes are presented which are at different stages of development and their viability in using high ash Indian Coal has been discussed. Apart from that different aspects of Coal \& Petroleum refinery are discussed too.

\section{STATUS OF COAL TO OIL TECHNOLOGY}

There are 3 leading processes of Coal to Oil but they are at different stages of development. H-Coal process of coal to oil through direct catalytic liquid phase hydrogenation is the only process which has been commercialised (2). For instance, a plant has been constructed in Mongolia (China) based on H-Coal and the plant is running. The cost of oil produced by $\mathrm{H}$-Coal is $\$ 60 / \mathrm{bbl}$. Oil yield is $4.5 \mathrm{bbl} /$ ton of coal (Maximum).
Out of the other two processes, one is nano-catalyst based direct liquefaction process which is also a liquid phase hydrogenation one and at present it is in Plot Plant Development stage. Oil yield is $5 \mathrm{bbl} /$ ton of coal and cost of oil is $\$ 40 / \mathrm{bbl}$. Catalyst concentration is $500 \mathrm{ppm}$ in coal + oil slurry which is hydrogenated (3).

The $3^{\text {rd }}$ process is also direct liquefaction process and it consists of solid phase (dry) hydrogenation. It is in Bench Scale Development stage. In this process either an impregnated hydrogenation(4) or cracking catalyst or a combination of two can be used. Alternatively, since coal already has in it mineral matters e.g. $\mathrm{Al}_{2} \mathrm{O}_{3}, \mathrm{SiO}_{2}$ \& $\mathrm{Fes}_{2}$ which are cracking and hydrogenation catalyst respectively (5) dry hydrogenation can be carried out without adding any external catalyst. Yield of oil is upto $4.5 \mathrm{bbl} /$ ton of coal and price is in the range of $\$ 35$ to $\$ 40 / \mathrm{bbl}$ depending on whether external catalyst is used or not because catalyst recovery is costly.

\section{VIABILITY OF USE OF HIGH ASH INDIAN COAL FOR LIQUEFACTION OF COAL}

Beneficiation of Coal prior to the front end of feeding coal to either liquid phase or dry hydrogenation process for liquefaction is possible.

In the final vacuum tower, operate the tower at proper vacuum level in order to have that amount of liquid so that the slurry containing all the ash is a dilute slurry that is pumpable to partial oxidation unit for producing Co \& $\mathrm{H} 2$ and discharge molten ash. Any excess $\mathrm{H}_{2}$ ends up with fuel gas. 
Although beneficiation may take care of a portion of ash removal, there may still be a significant amount left behind. Thus, in H-Coal process there may occur accumulation of ash in the reactor, unless the velocity of coal-oil slurry is high enough to sweep away the accumulated high density ash partides provided catalyst particles are large enough to remain floated in the ebullated bed reactor.

In Nano-catalyst based process since it is a moving bed reactor there may not occur any accumulation of ash in the reactor.

In solid phase hydrogenation using a box type preheater design using the principle of jet entrainment and zig zag flow of coal and $\mathrm{H}_{2}$ mixture, the MOC of the preheater has to be abrasion resistant due to high ash loading's impact on the wall of preheater (6).

Large quantity of ash generated in a Coal Refinery in India can be disposed of by using the same wagons which bring the coal from mines and take the ash back for filling up the mines due to the void created by coal mining so that the mine does not collapse.

\section{COMPARISON OF YIELD DISTRIBUTIONS OF VARIOUS PRODUCTS FROM COAL AND CRUDE PETROLEUM}

\begin{tabular}{|llll|}
\multicolumn{3}{c}{ Petroleum Coal (H-Coal) } \\
\hline [1]. & Naphtha & $5 \%$ & $22 \%$ \\
\hline [2]. & Petrol & $7 \%$ & $13 \%$ \\
\hline [3]. & Kerosene & $12 \%$ & $22 \%$ \\
\hline [4]. & Diesel & $19 \%$ & $10 \%$ \\
\hline [5]. & (HSD) & $37 \%$ & \\
\hline [6]. & Heavy ends $20 \%$ & $33 \%$ \\
\hline
\end{tabular}

The above yields are for once through process of crude distillation and coal hydrogenation. The Heavy ends can be hydrocracked to yield lighter products. Note that $\mathrm{H}$-Coal is the only direct process of coal liquefaction that has been commercialized. Nano-catalyst based direct coal liquefaction process yields more lighter products than heavy ones but this process is now at Pilot Plant stage of development. Based on $\mathrm{H}$-Coal process Diesel yields is much less than those obtained from petroleum whereas Naphtha and Kerosene yields are higher with coal.

\section{EMISSIONS AND EFFLUENT FROM COAL \& PETROLEUM REFINERY AND THEIR TREATMENT}

\section{Petroleum}

There are 3 types of effluent generated namely, solid, liquid and gaseous.

Solid - Waste Catalyst

Liquid - 600 to $700 \mathrm{~m}^{3} / \mathrm{hr}$ for a $150,000 \mathrm{bbl} /$ day

Refinery Effluent for which there is ETP in each refinery
Gaseous Effluent - Mostly $\mathrm{H}_{2} \mathrm{~S}$ from which ' $\mathrm{S}$ ' is recovered by Claus process.

2. Coal Refinery

(b) Ash

Solid Effluent : (a) Spent Catalyst

Liquid Effluent : Nil

Gaseous Effluent : $\mathrm{Co}_{2} \& \mathrm{H}_{2} \mathrm{~S}$

From the gaseous effluent $\mathrm{H}_{2} \mathrm{~S}$ can be utilized to recover elemental sulfur by using Claus process. The $\mathrm{Co}_{2}$ can be converted to useful chemicals e.g. methanol, ethanol, isopropanol by combining with $\mathrm{H}_{2}$ at atmospheric pressure in presence of Ni-Ga catalyst (7).

\section{CAPITAL INVESTMENT IN PETROLEUM AND COAL REFINERY}

(1) Petroleum (50,000 bbl/day)

Capital Investment is Rs. 4500/- crores based on Rs. 2000 crore/million ton/ annum (8)

\section{(2) Coal Refinery}

$\mathrm{H}$ - Coal Commercial Plant Actual Investment is \$ 2 billion $=13,000$ crore. Nano-catalyst based process's investment is $\$ 1.3$ billion $=8500$ crore, based on scale up of Pilot Plant Design Cost.

So, it is seen that Investment in a coal refinery is much higher than that for a Petroleum Refinery. Investment for Dry Hydrogenation Process will be however, less than Nano-Catalyst basedoprocts frome APU much smaller reactor size i.e. about Rs. 6000 crore but it may not be counted at the moment due to its development stage being still in Bench Scale (9).

\section{CHARACTERISTICS OF PETROLEUM DERIVED PRODUCTS VS. THOSE FROM COAL}

It is to be noted that coal derived liquids are mostly aromatic in nature compared to those from Petroleum which are mostly paraffinic. Thus, naturally Octane No. will be higher for coal derived liquids. However, petroleum derived liquids are treated for cyclization to improve the Octane No.

\section{CONCLUSION}

Under Indian scenario it is desirable that to meet increased demand of liquid fuel for vehicles with time, instead of building more refineries based on crude petroleum which has to be imported, coal refineries be built although investment is more because our government's foreign exchange reserve is of meagre amount. The Nano-catalyst based liquefaction process and dry hydrogenation process should be quickly scaled upto commercial scale so that plants can be constructed to supply future's increased demand of liquid products using these processes which produce oil at cheaper price and furthermore it is to be noted that oil price based on coal liquefaction technologies discussed ranges from $\$ 35$ to $\$ 60 / \mathrm{bbl}$ which is comparable to Petroleum derived products' price. 


\section{REFERENCES}

[1]. Report on Coal to oil, Dr. K.N. Bhattacharya, Central Mining And Fuel Research Institute, Dhanbad, India 2008.

[2]. 'H-Coal', ECN Petrochemical' 71 supplement, December 17, 1979.

[3]. 'Nano-Catalyst Based Process of Coal Liquefaction', Personal Communication with CEO of Energy Catalysis Inc. (New Jersey, USA), 2014.

[4]. 'Dry Hydrogenation Process of Coal to Oil', Personal Communication with Dr. W.C. Shrolder (USA); Inventor of the Process - US Patent (1964) 3, $152,063$.

[5]. 'The Relation of Coal Characteristics To Coal Liquefaction Behaviour', P.H. Givern, Pennsylnania State University; Report prepared for NSF (USA) 1974.

[6]. 'Upgraded Chemical Process Technology And Efficient Equipment'; A. Sirkar, New Age International Publishers, New Delhi, 2011.

[7]. Chemical Engineering Progress, April, 2014.

[8]. Personal Communication with Mr. Amar Nath Pal, Ex Employee of IOCL, Haldia Refinery, 2015.

[9]. Solid Phase Hydrogenation Cuts cost, W.C. Shroeder, Hydrocarbon Processing, January 1976.

\section{BIOGRAPHIES}

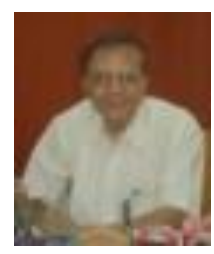

Professor Amalesh Sirkar is one of the renowned researcher on coal liquefaction process is working at HIT for 13 years. He owned seven patents on different fields including coal liquefaction process.

Email Id: sirkar_a@hotmail.com

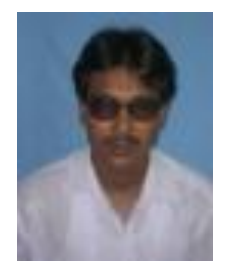

Biswajit Mandal is working as assistant professor in Chemical Engg. Department at Haldia Institute of Technology for seven years.

Email Id: bmandal_1977@rediffmail.com 